Int. J. Dev. Biol. 48: 599-606 (2004)

\title{
Pain control by ionizing radiation of bone metastasis
}

\author{
LUC A.M.-L. VAKAET* and TOM BOTERBERG \\ Department of Radiotherapy, Ghent University Hospital, Ghent, Belgium
}

\begin{abstract}
Pain treatment due to cancer is a large fraction of the care in a radiotherapy department. While radiation treatment is very effective in reducing pain, the pathophysiology of bone metastases remains very complex. Reducing the number of tumour cells by radiation will reduce the pressure in bone marrow, but the very rapid response to radiation treatment seen in some patients is probably related to the presence of highly radiosensitive inflammatory cells. In this review we give an overview of the pathophysiological mechanisms which lead to pain associated with bone metastasis and the impact of radiation treatment and other treatments on this mechanism.
\end{abstract}

KEY WORDS: bone metastasis, pain control, radiation therapy, pathophysiology

\section{Introduction}

Pain due to cancer is feared by every patient who is diagnosed with cancer because pain is associated with advanced disease, especially end-stage disease. About three quarters of patients with end-stage disease will eventually need pain management (Cleeland, 2000).

Palliative treatment is a significant part of cancer care in a radiotherapy department. A substantial proportion of that care is spent on palliative radiation treatment of painful osseous metastases. Radiation is very effective in providing pain relief. Almost two thirds of patients will experience improvement in their pain, with complete and long-lasting pain relief in about half of the patients (Bates, 1992 and Maher 1992). Although the skeleton receives only $10 \%$ of the cardiac output, metastases in the skeleton are very common as compared to metastases to other tissues receiving a far greater amount of the cardiac output. The pattern of distribution of bone metastasis in patients above 25 years follows the distribution of the red marrow with a particular high frequency of metastases in the spine, ribs, pelvis, skull and proximal femur (Debois, 2002). This highlights the dominant role of the bone marow in the pattern of spread of bone metastases. More rarely bone metastasis may develop in the first bone marrow a tumour cell encounters, according to the anatomic-mechanical theory (Aaron, 1997). This mechanism explains the bony metastatic spread of prostate cancer through the paravertebral venous plexus emanating from the pelvis. Chemotactic factors may play a role in directing tumour cells to the bone. Metastasis to the bone is a particular clinicopathologic entity that is clinically different from other types of metastatic spread. Breast cancer e.g. that has only metastasized to the bone has a better prognosis than when the breast cancer has spread to visceral organs.
The large majority of bone metastases originates from 8 primary tumours listed in Table 1. In recent years our knowledge about the mechanisms involved in the development of pain due to bone destruction has evolved considerably. Some of these molecular mechanisms provide new targets for drug development.

\section{The physiology of normal bone}

Normal bone is the result of a homeostatic process that preserves the structure and function of the skeleton. Bone is continually being deposited by osteoblasts and absorbed by osteoclasts. Osteoclasts are large multinucleated cells that are normally under the physiologic control of activating parathyroid hormone (PTH) on one hand and inhibiting calcitonin on the other (Guyton, 1986). The osteoclasts send out villus-like projections toward the bone and from these villi they secrete (1) osteolytic enzymes released from their lysosomes and (2) acids including citric and lactic acid. Fragments of the bone are then phagocytosed by the villi and further digested within the osteoclast. Normally, except in growing bones, the rates of bone deposition and absorption are equal so that the total mass of bone remains constant. PTH not only activates existing osteoclasts but also induces the formation of new osteoclasts from progenitor cells.

\section{Pathophysiology of bone metastasis}

A metastasis to the bone is a consequence of a cascade of events including (1) progressive growth at the primary site, (2) tumor neo-vascularization, (3) detachment of tumor cells from the primary tumour, (4) invasion in the neighbouring tissues (5) intravasation into the blood stream, (6) survival in the circulation, (7) homing and arrest at the level of the bone marrow, (8)

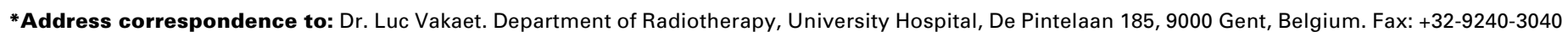
e-mail: vakaet@krtkg1.ugent.be
} 
extravasation, (9) evasion of the host defence, (10) growth and stimulation of the osteoclast mediated bone resorption (Mareel et al., 1991 and Choong, 2003). A list of possible mechanisms of tumor-induced bone pain is given in Table 2.

Metastasis to the bone (Fig. 1) leads to a complex cellular and molecular ecosystem with the involvement of a multitude of cells.

\section{Cancer cells}

The presence of large quantities of growth factors inside the actively proliferating bone marrow stimulates growth of metastatic tumour cells leading to a vicious cascade of events. Cancer cells - like inflammatory cells - release osteoclast activating factors, such as $\mathrm{PTH}$ and $\mathrm{PTH}$ releasing protein (PTHrP), Interleukin1(IL-1), IL-6, IL-11, Tumor Necrosis Factor (TNF), Transforming Growth Factor Beta (TGF- $\beta$ ), Epidermal Growth Factor (EGF), Platelet Derived Growth Factor (PDGF) and prostaglandins. All these molecules can trigger osteoblasts and stromal cells to stimulate the differentiation and fusion of osteoclast progenitor cells.

\section{Osteoclasts}

Activated osteoclasts eventually cause the breakdown of the bone matrix (reviewed in Mareel et al., 1991 and Mareel and Leroy, 2003). Osteoclasts are specialised cells that originate from monocyte precursor cells under the influence of RANKL, the ligand of the Receptor Activator of NF- $\kappa \mathrm{B}$ (RANK) on the osteoclast precursor. The naturally occurring decoy receptor osteoprotegerin (OPG), a member of the TNF receptor family, inhibits the effect of RANKL on osteoclast differentiation. RANKL is produced by osteoblasts and stromal cells as a regulator of bone formation and destruction (Kong et al., 1999). Free floating soluble RANKL is also able to stimulate the osteoclast progenitors. OPG is now being proposed in clinical trials for the treatment of bone metastasis through the capturing of the free floating RANKL molecules.

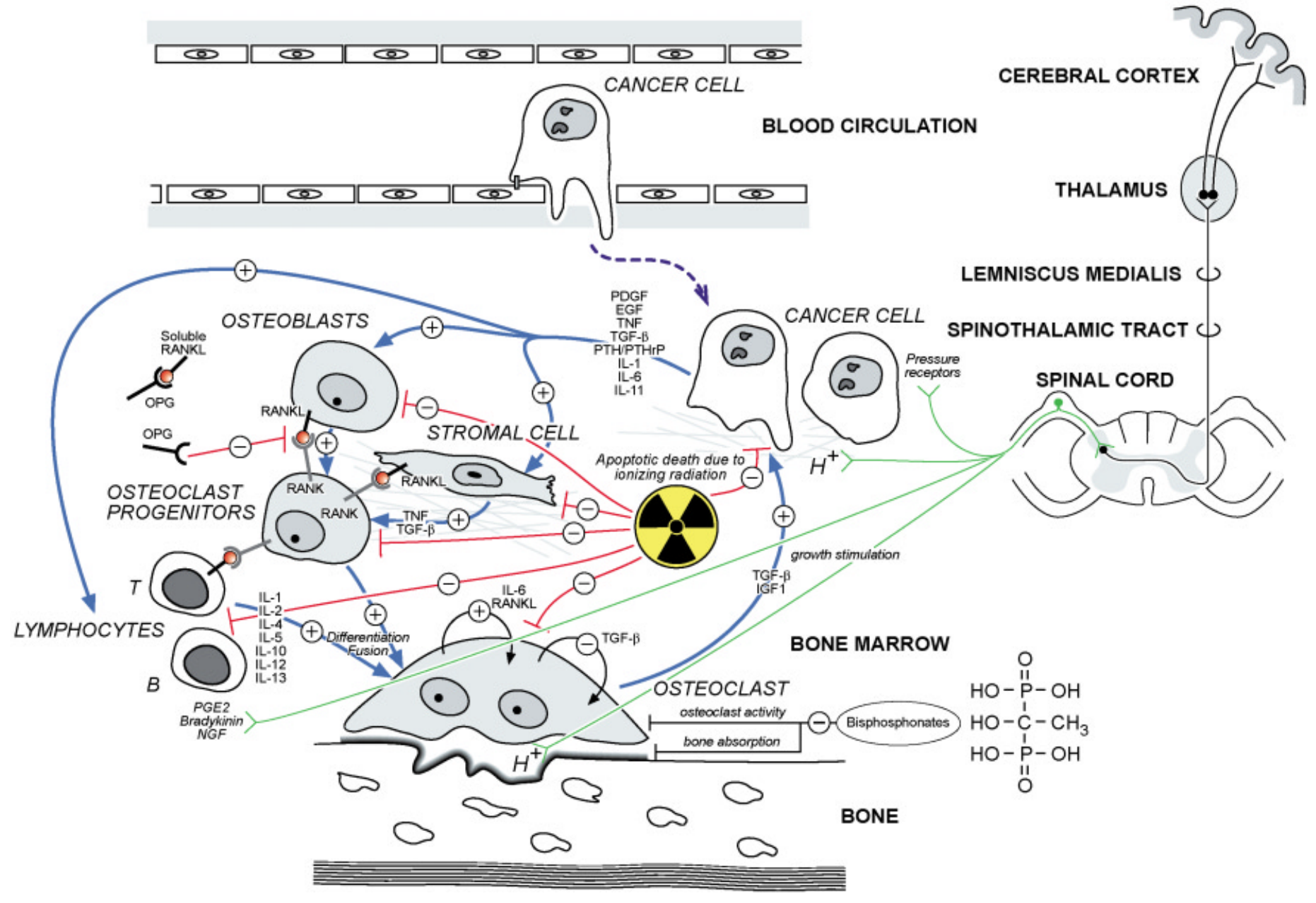

Fig. 1. The vicious circle of bone metastases. The vicious circle of a developing bone metastasis is represented by the thick blue arrows. Cancer cells inside the bone marrow produce a cascade of enzymes which - through stimulation of stromal cells, osteoblasts, lymphocytes and osteoclast progenitor cells - eventually stimulates osteoclasts to destroy the bone. At the right side of the figure, the physiological pain pathway is represented. Pain receptors capture different pain signals, which are transported via sensory neurons (in green) and the spinal chord to the thalamus and finally to cortical neurons. Radiation induces apoptotic death, not only of tumour cells (thereby reducing pressure) but also of all other cells in the cascade. Inhibitory effects of radiation are shown in red lines. The name of tissue is in bold capital print. The contributing cell types are in italic capital print. Cellular functions are in italic. Abbreviations of the molecules are explained in the text. (Not drawn to scale. Adapted from Mundy, 2002 and Mareel and Leroy, 2003). 
Amongst other functions RANKL will also induce lymphocyte development and can thus be involved in the inflammatory reaction in the immediate vicinity of metastatic tumor cells. Recently it was shown (Ogasawara et al., 2004) that RANKL was produced by the osteoclasts thus suggesting an autocrine stimulating loop inside the osteoclast in both physiological and pathological conditions.

\section{Stromal cells}

Other mechanisms that are involved in this tumour-host microevironment involve the TGF- $\beta$ and TNF produced by stromal cells. This particular pathway was recently documented to be essential in the development of bone lesions in rheumatoid arthritis (Redlich et al., 2004). TGF- $\beta$ promotes the production of PTHrP produced by bone cells and tumour cells that, in its turn, stimulates bone turnover by enhancing the osteolytic action of the osteoclasts (Guise, 1997). TGF- $\beta$ can, on the other side, also promote apoptosis of osteoclasts thereby reducing osteolysis. Recently it was shown that stromal cells - derived from normal bone marrow - produce monocyte chemotactic proteins (MCPs) that are involved in the bone marrow homing of multiple myeloma cell lines (Vande Broek et al., 2003).

\section{Inflammatory cells}

Prostaglandins - produced by the attracted inflammatory cells - are present in the bone metastasis micro-environment and induce further inflammation. Inflammation is a critical element in tumour progression. The tumour microenvironment is largely orchestrated by inflammatory cells (Coussens and Werb, 2002). Those inflammatory cells are responsible for the acute effects of inflammation, frequently resulting in pain. Synthesis and release of inflammatory cytokines mediate the effects. Cytokines can be defined as proteins produced by a cell in response to a variety of stimuli (Clemens, 1991). They are secreted by producer cells and then influence the behaviour of target cells. Many classes of cytokines are known: growth factors, lymphokines, colony stimulating factors, transforming growth factors, TNFs, interferons. It is important to realize that cytokines can be directly produced by the tumour cells, but are often produced in larger amounts by the inflammatory cells that are attracted by the tumour cells. The cytokines produced by the tumour cells usually aim at survival and proliferation of the tumour, while the cytokines produced by the inflammatory cells may help the organism to fight against the

TABLE 1

\section{INCIDENCE OF BONE METASTASES AT AUTOPSY} (ADAPTED FROM COLEMAN, 2001)

\begin{tabular}{lcc} 
Primary tumour & $\begin{array}{l}\text { Incidence of bone metasta- } \\
\text { sis in advanced disease }\end{array}$ & $\begin{array}{l}\text { Median time of survival (in months) } \\
\text { after diagnosis of bone metastases }\end{array}$ \\
\hline Myeloma & $70-95 \%$ & 24 \\
Breast & $65-75 \%$ & 36 \\
Prostate & $65-75 \%$ & 36 \\
Thyroid & $60 \%$ & 48 \\
Bladder & $40 \%$ & $6-9$ \\
Lung & $30-40 \%$ & 7 \\
Hypernefroma & $20-25 \%$ & 12 \\
Melanoma & $14-45 \%$ & 6 \\
\hline
\end{tabular}

cancer cells, resulting in an inflammatory reaction which frequently causes pain. This inflammatory reaction is a very complex system, with many synergistic and counteracting cytokines being present at the same moment. Moreover, many cytokines have overlapping biological effects. The synthesis and presence of cytokines will result in the production of other cytokines, with again different functions and effects, creating a complex network. The final result of this balance is often difficult to foresee and may explain why biological therapies targeted at one of those pathways, though in vitrotheoretically perfect, sometimes fail to work and may even have opposite effects in vivo. Blocking one pathway can force a cell to use another one as a kind of escape route, to eventually obtain the same effect, but via a previously unused and seemingly "redundant" mechanism (Haddad, 2002). TGF- $\beta$ is produced by cancer cells and can act as a growth factor for certain cells, but can also block the mitogenic effects of EGF, PDGF, fibroblast growth factor (FGF) and insulin (Clemens, 1991). Cancer cells losing the TGF- $\beta$ receptor will lose at least one survivallimiting factor. But, while inhibiting growth, TGF- $\beta$ at the same time stimulates osteoclasts and thereby helps the cancer cells to invade into the bone. Moreover, e.g. in colon cancer cells, TGF$\beta$ may transform fibroblasts into myofibroblasts which will secrete other factors that promote invasiveness of the cancer cells (De Wever and Mareel, 2003).

Although cancer cells are "self" and should not evoke an immune response, they are often surrounded by large amounts of inflammatory cells. In some cases these inflammatory cells may even make up more than $50 \%$ of the tumour cellular volume. This also explains the clinical experience that anti-inflammatory drugs, like steroids or non-steroidal anti-inflammatory compounds can give a (temporary) decrease in tumour volume. Even routine antibiotics may reduce tumour volume, of course only in cases of infected tumours that are heavily loaded by inflammatory cells. Tumour-associated antigens on cancer cells can be detected by immune cells and may hence elicit an immune response by e.g. macrophages, natural killer cells or cytotoxic T-cells. Those tumour antigens can be of viral origin (e.g. human T leukaemia virus I (HTLV-I), Epstein-Barr virus (EBV) or human papilloma viruses (HPV)) or specific tumour antigens can originate from mutated genes (Roitt, 1998). Necrotic tissue, the result of insufficient neovascularization and nutrient supply to a tumour, will also recruit inflammatory cells. The cytokine network produced by inflammatory cells is extremely complex. Monocytes are a major source of IL-1, but almost every cell type in the body can produce IL-1 under appropriate conditions. IL-1 will stimulate the immune response by recruiting other inflammatory cells like T-cells and by induction of the synthesis of other lymphokines. It will also

\section{TABLE 2}

\section{POSSIBLE LOCAL MECHANISMS OF INDUCING BONE PAIN}

Release of chemical mediators
Increased pressure within the bone
Microfractures
Stretching of the periosteum
Reactive muscle spasm
Nerve root infiltration
Compression of the nerves due to collapse of the bone


produce inflammatory responses via IL-1-induced production of prostaglandins. IL-1, but also TNF, activates the conversion of arachidonic acid into eicosanoids. Eicosanoids derived from arachidonic acid include the prostaglandins and thromboxanes (synthesized by cyclo-oxygenases) and leukotrienes (generated by lipoxygenases). Those inflammatory mediators also play a role in the development of pain. When T-lymphocytes are stimulated, e.g. by activated macrophages, a cascade of cytokine production will start. T-cells will not only produce IL-2, but will also increase the number of IL-2 receptors on their cell membrane, thus creating an autocrine loop resulting in a highly active immune response (Bucher et al., 1997). The so-called $T_{H} 1$ cells will secrete IFNgamma and TNF-alpha, which will activate even more macrophages, kill cancer cells and further activate the inflammatory response. Other T-cells ( $T_{H} 2$ cells) will secrete IL-4, IL-5, IL-10 and IL-13 to activate other pathways of the inflammatory response. IL-12, produced by B-cells, macrophages and dendritic cells, plays a key role by inducing $T_{H} 2$ development and inhibiting $\mathrm{T}_{H} 1$ development. Since inflammatory cells produce those cytokines, which are often involved in pain response, are highly radiosensitive, radiotherapy may have a quick analgesic effect by simply killing the inflammatory cells and thus breaking the cytokine cascade.

\section{Pain due to bone metastasis}

Pain from bone metastasis is frequently the first symptom for which the patients will seek advice (Mercadante, 1997). The origin of the pain from bone metastases is listed in Table 2. Pain is a complex experience that is based on the transduction of a noxious environmental stimulus in the periphery of the body and that is modulated by cognitive and emotional processing by the cortical neurons of the brain. The subjective nature of pain has hampered the development of randomised trials considerably and has recently lead to initiatives to promote a universal language when reporting the palliative antalgic effects of any form of therapy for bone metastases (Chow et al., 2002). In general there are two types of pain in patients with bone metastases. The first type is a continuous pain and is usually described as a dull aching pain that increases in severity over time. A second type of bone cancer pain

\section{TABLE 3}

THE CHANNELS OF THE PRIMARY AFFERENT NOCICEPTOR WHICH RESPOND TO DIFFERENT STIMULI PRESENT IN BONE METASTASES (ADAPTED FROM JULIUS AND BASBAUM, 2001)

\begin{tabular}{ll} 
Stimulus & Representative receptor/molecular targets \\
\hline Nerve Growth Factor (NGF) & $\begin{array}{l}\text { Transmembrane receptor Kinase A (TrkA) } \\
\text { Bradykinin }\end{array}$ \\
$\begin{array}{l}\text { Bradykinin (G-protein coupled) membrane } \\
\text { receptor }\end{array}$ \\
Serotonin & 5-Hydroxy Tryptamine receptor (5-HT3) \\
Adenosine tri phosphate (ATP) & ATP gated ion channel (P2X3) \\
$\mathrm{H}^{+}$ & Acid-sensing ion channel (ASIC3) \\
Vanilloid receptor (VR1) \\
Lipids & Prostaglandin E2 (PGE2) \\
VR1 & Degenerin family of ion channels (DEG/ENaC) \\
\hline
\end{tabular}

is movement-evoked, breakthrough or episodic and is more acute in nature (Portenoy et al., 1999).

The pain from bone metastasis can be explained by direct stimulation of afferent pain nerve fibres that are stimulated by mechanical injury or by a multitude of factors present in the complex microenvironment of bone metastases. Local tissue acidosis is a hallmark physiologic response to injury and inflammation and the degree of pain is correlated with the magnitude of acidification. A number of acid-sensing ion channels (ASIC3/VR1) are found on sensory neurons (Julius and Basbaum, 2001). Other channels involved in pain sensation are listed in Table 3.

\section{Effects of irradiation on bone metastasis}

The main goal of palliative radiation treatment is the relief of pain or dysfunction caused by the bone metastasis. For most patients who achieve pain relief after irradiation this lasts for two-thirds of their remaining life (Perez et al., 2004). Adequate management of this group of patients is important for a number of reasons: (1) Bone pain secondary to metastasis is the most common pain syndrome requiring palliative treatment in cancer patients; (2) Patients with predominant bone metastasis have longer duration of survival than patients with predominantly visceral metastasis; (3) Complications of bone metastasis are common and produce high morbidity.

It is a common misconception that ionizing radiation will result in a decrease in normal ossification. External beam irradiation produces ossification in $65 \%$ to $85 \%$ of lytic metastases in unfractured bone. Some of the ossification may occur by heterotopic ossification within the lesion, however, in most cases, there is formation of mature organized bone in the healed lesion, seemingly by direct osteogenesis (Perez et al., 2004).

\section{What is the target in external beam irradiation of bone metastasis?}

Although treatment by external irradiation is successful in most patients the exact mechanism of action is unknown (Hoskin, 2003). The doses used - though less than a radical course of radiotherapy - will cause high levels of tumour cell kill. There will therefore be a substantial reduction in the number of viable tumour cells within the radiation field and in due course this will result in shrinkage of the tumour bulk. Once the tumour cells are removed from the bone, osteoblastic repair will partially restore the integrity of the bone. Whilst this process undoubtedly occurs, the question arises as to whether this is the only explanation for the analgesic effect of radiation treatment. Certain features of the response - like pain diminishing after a few sessions - suggest that tumour shrinkage itself is unlikely to account for the early period of pain relief seen. The absence of a dose response relationship suggests that tumour shrinkage may not be that important since tumour shrinkage would not be expected with some of the very low single doses - down to $4 \mathrm{~Gy}$ - which have been shown to cause pain relief. Furthermore there appears to be no obvious relationship between the radiosensitivity of the primary tumour and the response on pain.

The striking clinical observation that some patients experience symptom relief within 24 hrs after the irradiation leads to the hypothesis that early reacting and very sensitive cells and the molecules they produce are involved in this answer. Obvious candidate cells are the inflammatory cells that are largely present 
in the bone metastasis micro-environment. Reduction by ionizing radiation of the inflammatory cells inhibits the release of chemical pain mediators and is probably responsible for the rapid reaction seen in some patients (Mercadante, 1997).

Other candidate cells are the osteoclasts. Osteoclastic activity is an early and important response to tumour cell invasion. The effect of anti-osteoclastic drugs, such as bisphosphonates, on bone pain hints to the prominent role of the osteoclast in mediating bone pain. Recently it has been demonstrated that urinary markers of bone resorption (and thus osteoclastic activity) and pain relief after radiation treatment were correlated (Hoskin et al., 2000). Doses of 5 Gy given to metatarsal bones of embryonic mice resulted in a selective elimination of the precursor cells for osteoclast formation (Scheven et al., 1986). A clear dose-response relationship between the dose of ionizing radiation and the decrease in osteoclast number in vitro was observed (Tsay et al., 1995). The calculated life span of the osteoclast in this study was 9 to 10 days. In a further investigation by the same group (Tsay et al., 1999) they showed that in the first weeks after exposure to moderate doses of ionizing radiation the number of osteoclasts did not diminish.

Other studies have shown that the influx of osteoclast precursor cells in vivois effectively suppressed by ionizing radiation (Comas, 1970). The resorbing activity of the osteoclast is less radiosensitive but can be inhibited, in a dose dependent way, by a dose of at least $5 \mathrm{~Gy}$, as was established by morphometric and biochemical methods in a mouse embryo model (Scheven et al., 1985). The authors hypothesize that two mechanisms could explain this change in resorbing activity: (1) interference with enzymatic processes involved in the resorption of cartilage matrix and mineral or (2) alterations in the mobility of the osteoclasts.

Another indirect hint to the importance of the effect of ionizing radiation on the inflammatory cell / osteoclasts comes from work done with cyclooxygenase-2 (COX-2) selective inhibitors. Selective COX-2 inhibitors have significantly fewer side effects than mixed non-steroidal anti-inflammatory drugs (NSAID) and can be used for longer periods than the mixed NSAIDs. In a mouse model it was shown that the chronic administration of a COX-2 inhibitor attenuated the pain, reduced the tumour burden, osteoclastogenesis and bone destruction by more than $50 \%$ (Sabino et al., 2002). In the control mice the increased bone resorption was explained largely by the sarcoma-induced osteoclast proliferation and hypertrophy. The COX-2 inhibitor reduced this proliferation and hypertrophy. Prostaglandins (particularly PGE2) modulate the osteoclast function and by reducing the production of $P G$ s there is a reduction in proliferation and hypertrophy of the osteoclasts. Besides the analgesic effect of ionizing radiation and bisphosphonates a secondary goal is the re-ossification of the osteolytic lesion. Thanks to the availability of highly efficient modern bisphopshonates for the treatment of osteolytic lesion most patients with bone metastasis will receive bisphosphonates as an additional treatment after external beam radiation.

\section{The dose, target volume and fractionation}

The target volume for primary irradiation of a bone metastasis is defined by the anatomical borders of the bone marrow compartments inside the bone. The margins are adjusted for motion uncertainty depending on the site of the bone metastasis.
Although a number of randomized trials have been carried out most of them were done on highly selected populations of patients due to the varying clinical presentation of bone metastases.

TABLE 4

RESULTS OF PUBLISHED CONTROLLED CLINICAL TRIALS ON DOSE AND FRACTIONATION FOR THE PALLIATION OF PAINFUL BONE METASTASES (UPDATE JAN 2004)

\begin{tabular}{|c|c|c|c|}
\hline Reference & Comparison ${ }^{1}$ & $\begin{array}{c}\text { Number of patients } \\
\text { Randomized }\end{array}$ & $\begin{array}{c}\text { Primary endpoint } \\
\text { p-value }\end{array}$ \\
\hline $\begin{array}{l}\text { Bone Pain Trial } \\
\text { Working Party } \\
1999\end{array}$ & $\begin{array}{l}\text { A: } 8 \text { Gy in } 1 \text { fraction vs } \\
\text { B: } 20 \text { Gy in } 5 \text { fractions or } \\
30 \text { Gy in } 10 \text { fractions }\end{array}$ & 761 & n.s. \\
\hline Cole 1989 & $\begin{array}{l}\text { A: } 8 \text { Gy in } 1 \text { fraction vs } \\
\text { B: } 24 \text { Gy in } 6 \text { fractions }\end{array}$ & 29 & n.s. \\
\hline Foro 1998 & $\begin{array}{l}\text { A: } 6 \text { Gy in } 1 \text { fraction vs } \\
\text { B: } 8 \text { Gy in } 1 \text { fraction }\end{array}$ & 50 & n.s. \\
\hline Gaze 1997 & $\begin{array}{l}\text { A: } 10 \text { Gy in } 1 \text { fraction vs } \\
\text { B: } 22.5 \text { Gy in } 5 \text { fractions }\end{array}$ & 265 & n.s. \\
\hline Hartsell 2003 & $\begin{array}{l}\text { A: } 8 \text { Gy in } 1 \text { fraction vs } \\
\text { B: } 30 \text { Gy in } 10 \text { fractions }\end{array}$ & 949 & n.s. \\
\hline Hirokawa 1988 & $\begin{array}{l}\text { A: } 25 \text { Gy in } 5 \text { fractions vs } \\
\text { B: } 30 \text { Gy in } 10 \text { fractions }\end{array}$ & 128 & n.s. \\
\hline Hoskin 1992 & $\begin{array}{l}\text { A: } 4 \text { Gy in } 1 \text { fraction vs } \\
\text { B: } 8 \text { Gy in } 1 \text { fraction }\end{array}$ & 270 & n.s. \\
\hline Jeremic 1998 & $\begin{array}{l}\text { A: } 4 \text { Gy in } 1 \text { fraction vs } \\
\text { B: } 6 \text { Gy in } 1 \text { fraction vs } \\
\text { C: } 8 \text { Gy in } 1 \text { fraction }\end{array}$ & 327 & $\begin{aligned} A & <B: p<0.025 \\
A & <C: p<0.0019\end{aligned}$ \\
\hline Kagei 1990 & $\begin{array}{l}\text { A: Single fraction vs } \\
\text { B: multiple fractions }\end{array}$ & 27 & n.s. \\
\hline Kirkbridge 2000 & $\begin{array}{l}\text { A: } 8 \text { Gy in } 1 \text { fraction vs } \\
\text { B: } 20 \text { Gy in } 5 \text { fractions }\end{array}$ & 398 & $A<B p=0.03$ \\
\hline Koswig 1999 & $\begin{array}{l}\text { A: } 8 \text { Gy in } 1 \text { fraction vs } \\
\text { B: } 30 \text { Gy in } 10 \text { fractions }\end{array}$ & 107 & n.s. \\
\hline Madsen 1983 & $\begin{array}{l}\text { A: } 20 \text { Gy in } 2 \text { fractions vs } \\
\text { B: } 24 \text { Gy in } 6 \text { fractions }\end{array}$ & 57 & n.s. \\
\hline Nielsen 1998 & $\begin{array}{l}\text { A: } 8 \text { Gy in } 1 \text { fraction vs } \\
\text { B: } 20 \text { Gy in } 4 \text { fractions }\end{array}$ & 239 & n.s. \\
\hline Niewald 1996 & $\begin{array}{l}\text { A: } 20 \text { Gy in } 5 \text { fractions vs } \\
\text { B: } 30 \text { Gy in } 15 \text { fractions }\end{array}$ & 97 & n.s. \\
\hline Okawa 1988 & $\begin{array}{l}\text { A: } 20 \text { Gy in } 10 \text { fractions vs } \\
\text { B: } 22.5 \text { Gy in } 5 \text { fractions vs } \\
\text { C: } 30 \text { Gy in } 15 \text { fractions }\end{array}$ & 80 & n.s. \\
\hline Porter 1993 & $\begin{array}{l}\text { A: }<10 \text { Gy in } 1 \text { fraction vs } \\
\text { B: } 20 \text { Gy in } 5 \text { fractions vs } \\
\text { C: } 30 \text { Gy in } 10 \text { fractions }\end{array}$ & 125 & n.s. \\
\hline Price 1986 & $\begin{array}{l}\text { A: } 8 \text { Gy in } 1 \text { fraction vs } \\
\text { B: } 30 \text { Gy in } 10 \text { fractions }\end{array}$ & 288 & n.s. \\
\hline Quilty 1994 & $\begin{array}{l}\text { A: Hemibody irradiation } 6 \text { Gy } \\
\text { in } 1 \text { fraction vs } \\
\text { B: Local irradiation } 20 \text { Gy in } 5 \\
\text { fractions vs } \\
\text { C: } 89-S r 200 \mathrm{MBq}\end{array}$ & 284 & n.s. \\
\hline Rasmusson 1995 & $\begin{array}{l}\text { A: } 15 \text { Gy in } 3 \text { fractions vs } \\
\text { B: } 30 \text { Gy in } 10 \text { fractions }\end{array}$ & 217 & n.s. \\
\hline Sarkar 2002 & $\begin{array}{l}\text { A: } 8 \text { Gy in } 1 \text { fraction vs } \\
\text { B: } 30 \text { Gy in } 10 \text { fractions }\end{array}$ & 85 & n.s. \\
\hline Steenland 1999 & $\begin{array}{l}\text { A: } 8 \text { Gy in } 1 \text { fraction vs } \\
\text { B: } 24 \text { Gy in } 6 \text { fractions }\end{array}$ & 1157 & n.s. \\
\hline Tong 1982 & $\begin{array}{l}\text { A: } 20 \text { Gy in } 5 \text { fractions vs } \\
\text { B: } 40.5 \text { Gy in } 15 \text { fractions }\end{array}$ & 266 & n.s. \\
\hline Total: & & 6206 & \\
\hline
\end{tabular}

${ }^{1} \mathrm{~Gy}=$ unit of dose, Gray.

2 n.s. $=$ not significantly different at the $5 \%$ level. 
An overview of all external radiation treatment trials concerning mainly the number of fractions given (McQuay et al., 2003) was brought up to date in this review through an extensive literature search (Falkmer et al., 2003 and Sze et al., 2003) and summarized in Table 4. All of the studies were randomized but blinding was often impossible. Radiotherapy, in these trials produced complete pain relief at one month in $25 \%$ of the patients. A relief of at least $50 \%$ at one month was achieved in $41 \%$ of patients. Analysing the various fractionation schedules there were no significant overall differences found. All trials taken together showed that half of the patients who achieved complete relief took four weeks to achieve it. With 43 different fractionation schedules, it was impossible to obtain the strength of evidence needed to show if there is a difference in efficiency between a single fraction and multiple fractions radiation treatment for pain relieve. Hypofractionated schedules result in somewhat more acute toxicity. The whole of the available evidence suggests however that an increase in the number of fractions does not translate in an increase of the therapeutic benefit. The RTOG trial 97-14 is an example of a large and recently reported trial that had as objectives (1) to determine whether $8 \mathrm{~Gy}$ in a single fraction provides equivalent pain relief compared to $30 \mathrm{~Gy}$ in 10 fractions for patients with painful bone metastasis, (2) to determine the duration of pain relief, (3) to determine the effect on quality of life measures; (4) to determine the incidence of pathologic fracture and (5) to determine cost-effectiveness of therapies in terms of cost/quality adjusted life years. Preliminary results (Hartsell et al., 2003) were presented in abstract form at the ASTRO meeting 2003 and confirm the data from the other trials: there was no difference in pain relief when comparing both treatment regimens.

We can conclude that single fraction radiation treatment compared to multiple-fraction radiation treatment provides equal palliation and quality of life and based on a Dutch study (Van den Hout et al., 2003) single fraction treatment has a lower medical and societal cost. Therefore single fraction radiation treatment is the treatment of choice for cancer patients with painful, uncomplicated bone metastases.

\section{The role of radioisotopes in the treatment of bone pain}

Recently a Cochrane review (Roqué et al., 2003) was presented on the use of radioisotopes for metastatic bone pain. Four trials (325 patients) were selected and they provide weak evidence for a small effect of radioisotopes on pain control both at short and medium term (one to six months). There is no available evidence for the effect of radioisotopes on fractures or quality of life. No evidence was available to assess long-term effects. Leukocytopenia and thrombocytopenia are secondary effects associated with the administration of radioisotopes. Rigorous parallel, double blind clinical trials including long-term evaluations and larger smple sizes are needed. The relative efficacy of the two most widely used isotopes (strontium-89 and samarium-153) should be compared in randomized studies. It is interesting to note that in some of the placebo controlled trials with strontium there were significantly fewer new pain sites in the patient that received strontium compared to the placebo group.

\section{The role of bisphosphonates}

Bisphosphonates are a class of pyrophosphate analogues that bind with high affinity to mineralized bone surfaces and inhibit osteoclastic bone resorption (Ashcroft et al., 2003). The mechanism of action of bisphosphonates is complex. They inhibit the mevalonate pathway, which results in the inhibition of osteoclast function (due to defects in intracellular vesicle transport and formation of ruffled borders) and the induction of apoptosis in osteoclasts and tumour cells alike (Green, 2002). There have been in vitrostudies that have shown tumour-cell apoptosis (Aparicio et al., 1998, Fromigue et al., 2000, Boissier et al., 2000). There is in vitro evidence (Boissier et al., 2000) that bisphosphonates inhibit tumor cell adhesion and invasion of the extracellular matrix. Bisphosphonates are used extensively to treat patients with diseases associated with bone loss such as osteoporosis and bone metastases. Bisphosphonates are now the treatment of choice in breast cancer-induced hypercalcaemia. They reduce bone pain and skeletal complications (Brown and Coleman, 2002). Recently the newer and highly-potent bisphosphonates (like zoledronate or ibandronate) are being evaluated in the adjuvant setting of breast cancer in order to reduce the risk of bone metastases and to treat breast cancer therapy-induced osteoporosis.

\section{Conclusions}

Efforts have been made in recent years to elucidate the biologic pathways that lead to painful bone metastases. This has lead to new ways to treat painful bone metastases and has also lead to a better insight in how radiation treatment is so successful in reducing the pain associated with bone metastases. Radiation treatment remains the most important palliative treatment for localized bone pain. Treatment duration can generally be reduced to a single treatment with excellent and long-lasting palliative analgesic responses. Current research focuses on the prevention of further bone-related events (bisphosphonates) and the incorporation of new biologic molecules (e.g. OPG) in the palliative treatment of bone metastases.

\section{Acknowledgement}

The authors wish to thank Prof. Marc Mareel for the opportunity to use his huge archive of scientific publications.

\section{References}

AARON, A.D. (1997). The management of cancer metastatic to bone. J. Am. Med. Assoc. 272:1206-1209.

APARICIO, A., GARDNER, A., TU, Y., SAVAGE, A., BERENSON, J. and LICHTENSTEIN, A. (1998). In vitro cytoreductive effects on multiple myeloma cells induced by bisphosphonates. Leukemia 12:220-229.

ASHCROFT, A.J., DAVIES, F.E. and MORGAN, G.J. (2003) Aetiology of bone disease and the role of bisphosphonates in multiple myeloma. Lancet Oncol. 4:284-292.

BATES, T. (1992). A review of local radiotherapy in the treatment a bone metastasis and cord compression. Int. J. Radiat. Oncol. Biol. Phys. 23:217-221.

BOISSIER, S., FERRERAS, M., PEYRUCHAUD, O., MAGNETTO, S., EBTINO, F.H., COLOMBEL, M., DELMAS, P., DELAISSE, J.M. and CLEZARDIN, P. (2000) Bisphosphonates inhibit breast and prostate carcinoma cell invasion, an early event in the formation of bone metastases. Cancer Res. 60:2949-2954.

BONE PAIN TRIAL WORKING PARTY. (1999). 8 Gy single fraction radiotherapy for the treatment of metastatic skeletal pain: randomized comparison with a multifraction schedule over 12 months of patient follow-up. Radiother. Oncol. 52:111-121.

BROWN, J.E. and COLEMAN, R.E. (2002). The present and future role of bisphosphonates in the management of patients with breast cancer. Breast Cancer Res. 4:24-29. 
BUCHER, P., CORTHEZY, P., IMBERT, J. and NABHOLZ, M. (1997) A conserved IL2 responsive enhancer in the IL-2Ralpha gene. Immunobiol. 198:136-143.

CHOONG, P.F.M., (2003). The molecular basis of skeletal metastases. Clin. Orthop. 415:S19-S31.

CHOW, E., WU, J.S., HOSKIN, P., COIA, L.R., BENTZEN, S.M. and BLITZER, P.H. (2002). International consensus on palliative radiotherapy endpoints for future trials in bone metastases. Radiother. Oncol. 64:275-280.

CLEELAND, C.S. (2000). Cancer-related symptoms Sem. Radiat. Oncol. 10:175190.

CLEMENS, M.J. (1991). Cytokines, Oxford, UK, BIOS Scientific Publishers.

COLE, D.J. (1989). A randomized trial of a single treatment versus conventional fractionation in the palliative radiotherapy of painful bone metastases. Clin. Oncol. 1:59-62.

COLEMAN, R.E. (2001). Metastatic bone disease: Clinical features, pathophysiology and treatment strategies. Cancer Treat. Rev. 27:165-176.

COMAS, F.V. (1970). The radiosensitivity of rat bone-marrow cells. Int. J. Radiat. Oncol. Biol. Phys. 17:549-557.

COUSSENS, L. and WERB, Z. (2002). Inflammation and cancer. Nature 420:860867.

DE WEVER, O. and MAREEL, M. (2003). Role of tissue stroma in cancer cell invasion. J. Pathol. 200:429-447.

DEBOIS, J.M. (2002). TXNXM1 The anatomy and clinic of metastatic cancer, Dordrecht The Netherlands, Kluwer Academic Publishers.

FALKMER, U., JARHULT, J., WERSALL, P. and CAVALLIN-STAHL, E. (2003). A systematic overview of radiation therapy effects in skeletal metastases. Acta Oncol. 42:620-633.

FORO, P., ALGARA, M., REIG, A., LACRUZ, M., MAYOL, S., LLONCH, C., AUNON, C. and VALLS, A. (1998). Randomized clinical trial comparing two schedules of treatment for painful bone metastases: 6 versus 8 Gy single doses. Radiother. Oncol. 48 S212 Abstr.834.

FROMIGUE, O., LAGNEAUX, L. and BODY, J.J. (2000). Bisphosphonates induce breast cancer cell death in vitro. J. Bone Miner. Res. 15:2211-2221.

GAZE, M.N., KELLY, C.G., KERR, G.R., CULL, A., COWIE, V.J., GREGOR, A., HOWARD, G.C. and RODGER, A. (1997). Pain relief and quality of life following radiotherapy for bone metastases: a randomized trial of two fractionation schedules. Radiother. Oncol. 45:109-116.

GREEN, J.R. (2002) Bisphosphonates in cancer therapy. Curr. Opin. Oncol. 14:609615.

GUISE, T.A. (1997). Parathyroid hormone-related protein and bone metastasis. Cancer, 80(8 suppl):1572-1580.

GUYTON, A.C. (1986). Textbook of medical physiology. 7th edition, WB Saunders Company, Philadelphia.

HADDAD J.J. (2002). Cytokines and related receptor-mediated signaling pathways. Biochem. Biophys. Res. Commun. 297:700-713.

HARTSELL, W.F., SCOTT, C., BRUNER, D.W., SCARANTINO, C.W., IVKER, R., ROACH, M., SUH, J., DEMAS, W., MOVSAS, B., PETERSEN, I. and“KONSKI, A. (2003). Phase III randomized trial of $8 \mathrm{~Gy}$ in 1 fraction versus $30 \mathrm{~Gy}$ in 10 fractions for palliation of painful bone metastases: Preliminary results of RTOG 97-14 Int. J. Radiat. Oncol. Biol. Phys. 57:S124.

HIROKAWA, Y., WADASAKI, K., KASHIWADO, K., KAGEMOTO, M., KATSUTA, S., HONKE, Y., KOYAMA, T., MAKIDONO, Y., KATAYAMA, H. and KISO, T. (1988). [A multi institutional prospective randomized study of radiation therapy of bone metastases]. [Japanese] Nippon Igaku Hoshasen Gakkai Zasshi48:1425-1431.

HOSKIN, P.J. (2003) Bisphosphonates and radiation therapy for palliation of metastatic bone disease. Cancer Treat. Rev. 29:321-327.

HOSKIN, P.J., PRICE, P., EASTON, D., REGAN, J., AUSTIN, D., PALMER, S. and YARNOLD, J.R. (1992) A prospective randomised trial of 4 Gy or 8 Gy single doses in the treatment of metastatic bone pain. Radiother. Oncol. 23:74-78.

HOSKIN, P.J., STRATFORD, M.R.L., FOLKES, L.K., REGAN, J.V. and YARNOLD, Y.R. (2000). Effect of local radiotherapy for bone pain on urinary markers of osteoclast activity. Lancet355:1428-1429.

JEREMIC, B., SHIBAMOTO, Y., ACIMOVIC, L., MILICIC, B., MILISAVLJEVIC, S., NIKOLIC, N., ALEKSANDROVIC, J. and IGRUTINOVIC, I. (1998). A randomized trial of three single-dose radiation therapy regimens in the treatment of metastatic bone pain. Int. J. Radiat. Oncol. Biol. Phys. 42:161-167.
JULIUS, D. and BASBAUM, A. (2001). Molecular mechanisms of nociception. Nature 413:203-210.

KAGEI, K., SUZUKI, K., SHIRATO, H., NAMBU, T., YOSHIKAWA, H. AND IRIE, G. (1990). [A randomized trial of single and multifraction radiation therapy for bone metastasis: a preliminary report]. [Japanese] Gan No Rinsho 36:2553-2558.

KIRKBRIDE, P., WARDE, P.R., PANZARELLA, T., ASLANIDIS, J., MCKENZIE, M. and SUN, A. (2000). A randomised trial comparing the efficacy of a single radiation fraction with fractionated radiation therapy in the palliation of skeletal metastases. Int. J. Radiat. Oncol. Biol. Phys. 48(suppl 3):185.

KONG, Y.Y., BOYLE, W.J. and PENNINGER, J.M. (1999). Osteoprotegring ligand: a common link between osteoclastogenesis, lymph node formation and lymphocyte development. Immunol. Cell Develop. 77:188-193.

KOSWIG, S. and BUDACH, V. (1999). [Recalcification and pain relief following radiotherapy for bone metastases. A randomized trial of two different fractionation schedules (10 times 3 Gy vs 1 time 8 Gy)]. [German] Strahlenther. Onkol. 175:500508.

MADSEN, E.L. (1983). Painful bone metastases: efficacy of radiotherapy assessed by the patients: a randomized trial comparing 4 Gy $X 6$ versus 10 Gy X 2. Int. J. Radiat. Oncol. Biol. Phys. 9:1775-1779.

MAHER, E.J. (1992). The use of palliative radiotherapy in the management of breast cancer. Eur. J. Cancer28:706-710.

MAREEL, M. AND LEROY, A. (2003). Clinical, cellular and molecular aspects of cancer invasion. Physiol. Rev. 83:337-376.

MAREEL, M.M., DE BAETSELIER, P. and VAN ROY, F.M. (1991) Mechanisms of invasion and metastasis. Boca Raton, FL., Ann Arbor, Boston, MD, CRC Press.

MCQUAY, H.J., COLLINS, S.L., CARROLL, D. and MOORE, R.A. (2003). Radiotherapy for the palliation of painful bone metastases (Cochrane Review). In: The Cochrane Library, Chichester, UK, John Wiley \& Sons, Ltd.

MERCADANTE, S. (1997). Malignant bone pain: pathophysiology and treatment. Pain 69:1-18.

MUNDY, G.R. (2002). Metastasis to bone: causes, consequences and therapeutic opportunities. Nature Rev. 2:584-593.

NIELSEN, O.S., BENTZEN, S.M., SANDBERG, E., GADEBERG, C.C. and TIMOTHY, A.R. (1998). Randomized trial of single dose versus fractionated palliative radiotherapy of bone metastases. Radiother. Oncol. 47:233-240.

NIEWALD, M., TKOCZ, H.J., ABEL, U., SCHEIB, T., WALTER, K., NIEDER, C., SCNABEL, K., BERBERICH, W., KUBALE, R. and FUCHS, M. (1996). Rapid course radiation therapy versus more standard treatment: a randomized trial for bone metastases. Int. J. Radiat. Oncol. Biol. Phys. 36:1085-1089.

OGASAWARA, T., YOSHIMINE, Y., KIYOSHIMA, T., KOBAYASHI, I., MATSUO, K., AKAMINE, A. and SAKAI, H. (2004) In situ expression of RANKL, RANK, osteoprotegerin and cytokines in osteoclasts of rat periodontal tissue. J. Periodont. Res. 39:42-49.

OKAWA, T., KITA, M., GOTO, M., NISHIJIMA, H. and MIYAJI, N. (1988). Randomized prospective clinical study of small, large and twice-a-day fraction radiotherapy for painful bone metastases. Radiother. Oncol. 13:99-104.

PEREZ, C.A., BRADY, L.W., HALPERIN, E.C. and SCHMIDT-ULLRICH, R.K. (2004). Principles and Practice of radiation oncology. Philadelphia PA, Lippincott Williams \& Wilkins, Fourth Edition.

PORTENOY, R.K., PAYNE, D. and JACOBSEN, P. (1999). Breakthrough pain: characteristics an impact in patients with cancer pain. Pain, 81: 129-134.

PORTER, A.T., MCEWAN, A.J., POWE, J.E., REID, R., MCGOWAN, D.G., LUKKA H., SATHYANARAYANA, J.R., YAKEMCHUK, V.N., THOMAS, G.M., ERLICH, L.E., CROOK, J., GULENCHYN, K.Y., HONG, K.E., WESLOWSKI, C. and YARDLEY, J. (1993). Results of a randomized phase-III trial to evaluate the efficacy of Strontium-89 adjuvant to local field external beam irradiation in the management of endocrine resistant metastatic prostate cancer. Int. J. Radiat. Oncol. Biol. Phys. 25:805-813.

PRICE, P., HOSKIN P.J., EASTON, D., AUSTIN, D., PALMER, S.G. and YARNOLD, J.R. (1986). Prospective randomised trial of single and multifraction radiotherapy schedules in the treatment of painful bony metastases. Radiother. Oncol. 6:247255

QUILTY, P.M., KIRK, D., BOLGER, J.J., DEARNALEY, D.P., LEWINGTON, V.J., MASON M.D., REED, N.S., RUSSELL, J.M. and YARDLEY, J. (1994). A comparison of the palliative effects of strontium-89 and external beam radiotherapy in metastatic prostate cancer. Radiother. Oncol. 31:33-40. 
RASMUSSON, B., VEJBORG, I., JENSEN, A.B. ANDERSSON, M., BANNING. A.M., HOFFMANN, T., PFEIFFER, P., NIELSEN, H.K. and SJOGREN, P. (1995). Irradiation of bone metastases in breast cancer patients: a randomized study with 1 year follow-up. Radiother. Oncol. 34:179-184.

REDLICH, K., GÖRTZ, B., HAYER, S., ZWERINA, J., DOERR, N., KOSTENUIK, P., BERGMEISTER, H., KOLLIAS, G., STEINER, G., SMOLEN, J.S. and SCHETT, G. (2004). Repair of local bone erosions and reversal of systemic bone loss upon therapy with anti-Tumor Necrosis Factor in combination with Osteoprotegerin or Parathyroid Hormone in Tumor Necrosis Factor-mediated arthritis. Am. J. Pathol. 164:543-555.

ROQUÉ, M., MARTINEZ, M.J., ALONSO, P., CATALA, E., GARCIA, J.L. and FERRANDIZ, M. (2003). Radioisotopes for metastatic bone pain (Cochrane Review). In: The Cochrane Library, 4 Chichester, UK: John Wiley \& Sons.

ROITT, I., BROSTOFF, J. and MALE, D. (1998). Immunology, Oxford, UK, Mosby International.

SABINO, M.A.C., GHILARDI, J.R., JONGEN, J.L.M., KEYSER, C.P., LUGER, N.M., MACH, D.B., PETERS, C.M., ROGERS, S.D., SCHWEI, M.J., DE FELIPE, C. and MANTYH, P.W. (2002). Simultaneous reduction in cancer pain, bone destruction and tumor growth by selective inhibition of Cyclooxygenase-2. Cancer Res. 62:7343-7349.

SARKAR, S.K., SARKAR, S.K., PAHARI, B. and MAJUMBAR, D. (2002). Multiple and single fraction palliative radiotherapy of bone secondaries - A prospective study. Ind. J. Radiol. Imaging 12:281-284.

SCHEVEN, B.A.A., BURGER, E.H., KAWILARANG-DEHAAS, E.W.M., WASSENAAR, A.M. and NIJWEIDE, P.J. (1985). Effects of ionizing radiation and resorbing activity of osteoclasts in vitro. Lab. Invest. 53:72-79.

SCHEVEN, B.A.A., KAWILARANG-DE HAAS E.W.M., WASSENAAR, A.M. and NIJWEIDE, P.J. (1986). Differentiation kinetics of embryonic bones in vivoand in vitro, Anat. Rec. 214:418-423.
STEENLAND, E., LEER, J.W., VAN HOUWELINGEN, H., POST, W.J., VAN DEN HOUT, W.B., KIEVIT, J., DE HAES, H., MARTIJN, H., OEI, B., VONK, E., VAN DERSTEEN-BANASIK, E., WIGGENRAAD, R.G., HOOGENHOUT, J., WARLAMRODENHUIS, C., VAN TIENHOVEN, G., WANDERS, R., POMP, J., VAN REIJN, M., VAN MIERLO, I., RUTTEN, E., LEER, J. and VAN MIERLO, T. (1999). The effect of a single fraction compared to multiple fractions on painful bone metastases: a global analysis of the Dutch Bone Metastasis Study Radiother. Oncol. 52:101-109.

SZE, W.M., SHELLEY, M.D., HELD, I., WILT, T.J. and MASON, M.D. (2003). Palliation of metastatic bone pain: single fraction versus multifraction radiotherapy - A systematic review of randomised trials. Clin. Oncol. 15:345-352.

TONG, D., GILLICK, L. and HENDRICKSON, F.R. (1982). The palliation of symptomatic osseous metastases: Final results of the study by the Radiation Therapy Oncology Group. Cancer 50:893-899.

TSAY, T.P., CHEN, M.H., OYEN, O.J., HAHN, S.S. and MARTY, J.J. (1995). The effect of cobalt- 60 irradiation on bone marrow cellularity and alveolar osteoclasts. Proc. Natl. Sci. Counc. Repub. China B19:185-195.

TSAY, T.P., CHEN, M.H. and OYEN, O.J. (1999). Osteoclast activation and recruitment after application of orthodontic force. Am. J. Orthod. Dentofacial Orthoped. 115:323-330.

VANDE BROEK, I., ASOSINGH, K., VANDERKERKEN, K., STRAETMANS, N., VAN CAMP, B. and VAN RIET, I. (2003). Chemokine receptor CCR2 is expressed by human multiple myeloma cells and mediates migration to bone marrow stromal cell-produced monocyte chemotactic proteins MCP-1, -2 and -3. Br. J. Cancer 88:855-862.

VAN DEN HOUT, W.B., VAN DER LINDEN, Y.M., STEENLAND, E., WIGGENRAAD, R.G.J., KIEVIT, J., DE HAES, H. AND LEER, J.W.H. (2003). Single- versus multiple-fraction radiotherapy in patients with painful bone metastases: cost-utility analysis based on a randomized trial. J. Natl. Cancer Inst. 95:222-229. 